\title{
Factors Affecting Startup Performance of Small and Medium-Sized Enterprises in Danang City
}

\author{
Tan Le Trinh
}

\section{A B S T R A C T}

Objective: The aim of the study is to examine the factors such as government policy, financial capital, cultural factors, social factors, and human capital that influence SMEs business success.

Research Design \& Methods: By observing many factors that affect businesses, this study applies structural equation modeling using partial least squares (PLS-SEM) to provide an understanding on how people may start their business. These factors help to reduce risks of failure and in-crease chances of success.

Findings: The results of testing indicate the suitability of the research model with data's re-search. Along with the acceptance of hypotheses, this research model shows the prac-tical meaning of startup performance.

Implications \& Recommendations: For a sustainable startup, there should be suitable legal policies, including incentive policies on taxes in the first 3-5 years, when new businesses are established. Moreover, we should focus on policies such as credit, guarantee, and loan assistance for startup enterprises in their initial stages to solve their problems.

Contribution \& Value Added: Many young people in Danang are entrepreneurs. The government also supports these activities and readily assists startup project effectiveness. Therefore, this study helps to understand the factors that affect startup performance.

\begin{tabular}{lll}
\hline Article type: & $\begin{array}{l}\text { research article } \\
\text { Keywords: }\end{array}$ & $\begin{array}{l}\text { structural equation model; partial least squares; startup performance; } \\
\text { small and medium sized enterprises; business environment }\end{array}$ \\
JEL codes: & C12, L26 & \\
\hline \multicolumn{4}{l}{ Received: 11 April 2019} & Revised: 15 August 2019 & Accepted: 25 August 2019 \\
\hline
\end{tabular}

Suggested citation:

Le Trinh, T. (2019). Factors Affecting Startup Performance of Small and Medium-Sized Enterprises in Danang City. Entrepreneurial Business and Economics Review, 7(3), 187-203. https://doi.org/10.15678/EBER.2019.070310 


\section{INTRODUCTION}

This study aims to identify the factors that affect startup performance of small and mediumsized enterprises (SMEs) in Danang city and to test the relationships among these factors. All previous studies addressed whether there are any clear characteristics, which detect small business barriers to find out which ones are more important for policy makers to help them. The question remains why some of them can lead to success but many cannot survive in competitive markets. These situations caused great concerns for researchers, because market economy relies on developing startup of substantial business numbers and the growth of such firms. Moreover, building those businesses creates more job opportunities for people in Danang, so the current study may help policymakers. In order to achieve this objective, this study employs a qualitative method of focus group discussion with chief executive officers of SMEs in Danang city to identify factors affecting startup performance and corresponding measure items. Furthermore, this study applies a quantitative method with PLS-SEM to construct an equation about factors that affect successful startup performance. There are five sections in this study (i) The Introduction section shows the essence and importance of this study; (ii) In order to construct the conceptual model, the numerous prior research and studies relating to entrepreneurship were reviewed and discussed in the Literature Review section; (iii) Besides, this study offers statistics analyzing and steps in a research process in the Material and Method section; (iv) what is more the empirical results are followed with the discussion, and the Results and Discussion section gives overview of the statistics results; (v) Finally, conclusions are drawn and recommendations are proposed.

\section{LITERATURE REVIEW}

\section{Startup Ecosystem (SE)}

The concept of startup ecosystem is widely used in the context of innovation and entrepreneurship. Although there is no single official definition for a startup ecosystem and the term is used in different ways, it typically refers to a specific geographic area with high density of startup companies and entrepreneurs. Herrmann et al. (2015), Ács, Autio, and Szerb (2013), but also Mason and Brown (2014) highlight the important role of entrepreneurs within the ecosystem and introduce the concept of entrepreneurial ecosystem in place of startup ecosystem. Those authors define that 'entrepreneurial ecosystem is a set of interconnected entrepreneurial actors, both potential and existing, entrepreneurial organization such as firms, venture capitalists, business angels, banks, institutions, and entrepreneurial processes like the business birth rate, the number of high-growth firms, the level of "blockbuster entrepreneurship," the number of serial entrepreneurs, the degree of sellout mentality among firms, and the level of entrepreneurial ambition. These elements formally and informally coalesce to connect, mediate, and govern the performance in the local entrepreneurial environment.' According to Mitchell (2002), entrepreneurial startups are measured by such groups of factors as relevance (the satisfaction of internal and external customer management, the involvement of human resource management in the process of implementing a strategic plan, other parts involved in human resource management), effectiveness (in leadership style, strategic management, relationship between the efficiency of profit and labor growth, and between business growth and labor cost), 
financial availability (the investment in infrastructure and technology, the investment in human resources), organizational culture, workforce size, training, and retraining. These groups of factors are influenced by internal and external business environment.

Another approach to the success factors of ecosystems is provided by Isenberg (2011) who identifies six different domains of entrepreneurship ecosystems: the policy of leadership and government, finance (financial capital), culture (success stories, societal norms), supportive factors (infrastructure, support professions, nongovernmental institutions), human capital (labor, educational institutions), and market networks.

Tsujimoto et al. (2017) present an integrated model of the existing literature. Furthermore, those authors propose an original definition of the ecosystem and the concept of a coherent ecosystem. This coherence is the core concept that underlies the explanation of dynamic evolution or extinction of the ecosystem. This is why we propose the following hypotheses:

H3: Entrepreneurial ecosystem is positively associated with startup ecosystem.

H4b: Human capital is positively associated with startup ecosystem.

H5b: Financial capital is positively associated with startup ecosystem.

H6b: Cultural factors are positively associated with startup ecosystem.

H7b: Social factor is positively associated with startup ecosystem.

H8b: Government policy is positively associated with startup ecosystem.

\section{Startup Performance (SP)}

A startup is a new business venture designed to effectively develop and validate a scalable business model (Katila, Chen, \& Piezunka, 2012). This is particularly the case of SMEs focused on providing products and services through startup performance. Startup performance by creating new businesses is a driving force for economic development. International studies by Radas and Bozic (2009) and Zain and Kassim (2012) show that there is a close relationship between business startups and regional and local economic growth.

According to Audretsch and Keilbach (2004), there are four effective factors among business startups: material capital, human capital, knowledge, and entrepreneurial capital that affects business performance.

International expertise shows that - among the many proposed solutions - business incubation seems to be one of the most effective means for assisting entrepreneurs in starting a new business, as it nurtures young enterprises and helps them survive during the vulnerable startup period (Szabó, 2006).

According to Radas and Bozic (2009), Zain and Kassim (2012), as well as Audretsch and Keilbach (2004), there are two main factors that include entrepreneurial ecosystem startup ecosystem into SMEs startup performance in the Central Region of Vietnam in terms of spatial dimension. This is why we propose the following hypotheses:

H1: Entrepreneurial ecosystem is positively associated with startup ecosystem.

H2: Human capital is positively associated with startup ecosystem.

\section{Entrepreneurial Ecosystem (EE)}

In recent years, the fields of entrepreneurship studies, economic geography, urban economics, and the economics of entrepreneurship have moved closer to each other through research on the context of entrepreneurship (Ucbasaran, Westhead, \& Wright, 
2001; Welter, 2011). According to Erik and Ben (2016), entrepreneurial ecosystems are a set of interdependent actors and factors coordinated in such a way that they enable productive entrepreneurship within a particular territory. The World Economic Forum (2013, pp. 6-7) shows that there are some key factors in successful ecosystems like human capital or finance, and supportive factors like entrepreneurs' talent, form of government, regulatory framework, informal institutions that enable entrepreneurship, and finally, domestic and foreign markets. Besides, Isenberg (2011) offers four defining characteristics for the entrepreneurship ecosystem:

- The entrepreneurship ecosystem consists of six domains that include (i) a conducive culture, (ii) enabling policies and leadership, (iii) availability of appropriate finance, (iv) quality human capital, (v) venture-friendly markets for products, and (vi) a range of institutional and infrastructural supports;

- Each entrepreneurship ecosystem is unique;

- Specifying generic root causes that the entrepreneurship ecosystem has limited practical value;

- Entrepreneurship ecosystems become (relatively) self-sustaining. An ecosystem is not complete and whatever available is in infancy stage.

Challenges remain for the effective intervention at strategic, institutional, and enterprise levels to streamline and trigger entrepreneurship development. However, there are huge opportunities and the government reforms are happening (Rahatullah, 2013). Zimmerman (2008) found a strong acceptance of entrepreneurship as an addition to the curriculum of business schools, resulting in increases in courses, faculty, endowed chairs, and publications in the field.

Neeraj (2018) offers a theory of entrepreneurial ecosystems that predict the initial funding of a startup based on the education, gender, and experience of the founder that funds the startup, which ultimately helps to improve the efficiency of entrepreneurial ecosystem. Therefore, I select some dominant factors that affect the entrepreneurial ecosystem in case of Danang province.

Hypothesis 4a (H4a): Human Capital is positively associated with Entrepreneurial ecosystem.

Hypothesis 5a ( $\mathrm{H} 5 \mathrm{a})$ : Financial Capital is positively associated with Entrepreneurial ecosystem.

Hypothesis 6a ( $\mathrm{H6a})$ : Cultural Factors is positively associated with Entrepreneurial ecosystem.

Hypothesis 7a (H7a): Social Factor is positively associated with Entrepreneurial ecosystem.

Hypothesis 8a (H8a): Government Policy is positively associated with Entrepreneurial ecosystem.

\section{Human Capital (HC)}

For many years now, there are studies into factors that affect startup performance (Elfring \& Hulsink, 2007; Gilbert, McDougall, \& Audretsch, 2006). The most prominent of these studies scrutinizes the role of human capital in the development of enterprises, in particular SMEs (Coleman, 2007). Moreover, based on resource-based theory, Ahmad and Hoffman (2008) argue that human resources can create competitive advantage for startups. On the other 
hand, Samad (2013) defines human capital as the ability to manage a business and argues that a firm that has and uses its management skills effectively will stay in business. In short, human capital contributes significantly to improving startup performance.

Similarly, recent research by Hisrich and Drnovsek (2002) shows that management capacity, expressed by education level, management experience, entrepreneurial experience, and the knowledge of business, positively impact the performance of newly established SMEs. In contrast, some studies provide no evidence of a positive relationship between human capital and performance (Appuhami, 2007). Moreover, Subramony et al. (2018) and Schwarz (2017) agree that human capital is a direct factor affecting the business performance of enterprises.

\section{Financial Capital (FC)}

The financial capital of a startup company usually comes from credit or from own company (Marshall \& Samal, 2006). However, SMEs or businesses in the agricultural sector have limited access to finance from financial organizations. Therefore, the financial capital of these enterprises is mainly based on debt and equity (Van Praag, 2003). Pretorius and Shaw (2004) divide financial resources into internal and external. The majority of SMEs' financial capital depends on internal resources, but this source is often not enough for the business to survive and develop, especially as it faces fierce competition in the global market. Therefore, external financing becomes very necessary for SMEs. Bollingtoft et al. (2003) along with Wiklund and Shepherd (2005) argue that financial shortfalls are one of the major causes of failure in the operation of SMEs. In general, most of the research argues that financial capital plays a very important role in fostering startup performance, especially in the case of SMEs.

\section{Cultural Factors (CF)}

According to Gudmundson, Tower, and Hartman (2003), culture has a profound impact on the success of a company or organization. Possession of positive cultural characteristics provides organizations with necessary ingredients. Culture has several elements that may serve to enhance or inhibit startup performance. Moreover, according to another recent research (Körner, 2015), there exists a strong positive correlation between participative management practices and cultural factors in small companies. Hurley and Hult (1998) emphasize the critical role of culture in improving the ability of a successful firm. Cultural factors can encourage or discourage a variety of behaviors and decisions, including those related to startup performance.

\section{Social Factors (SF)}

Although there are many different studies about social capital, researchers advocate the benefits of this funding for startup business success. One of the reasons given by Florin, Lubatkin, and Schulze (2003) is that high levels of social capital base on good reputation, professional experience, and direct personal relationships. In addition to these benefits, social capital also facilitates the development of other resources and thus the survival of the enterprise (Brüderl \& Preisendorfer, 1998). Compared to large-scale businesses, SMEs are more likely to develop social capital as they are closer to their customers. Thus, SMEs gain more direct and rapid knowledge (Wong \& Aspinwall, 2004). Okten and Osili (2004) empirical results show the positive impact of social capital on the development of SMEs, especially on 
their relationships with other firms. Similarly, Hayer, and Ibeh (2006) show that social capital is one of the important factors that facilitate SMEs in their internationalization.

Głodowska, Wach, and Pera (2016) find that pull factors have a positive influence on the level of internationalization of examined businesses. Production companies are the main beneficiaries of the internationalization process and Polish born globals take advantage of their adjustments to the environment.

\section{Government Policy (GP)}

Scholars established that entrepreneurship is the vital ingredient of job creation along with economic development, as the success of income generation for the majority of both rural and urban inhabitants without recognized paid job highly depends on entrepreneurship (Ihugba, Odii, \& Njoku, 2014).

Kumar and Liu (2005) reveal that entrepreneurial sector's contribution to employment and GDP increases. For this reason, governments should minimize constraints on entrepreneurship. In the case of government support policies, Kumar and Liu (2005) assume that government leads entrepreneurial development. Such resources include the provision of an environment conducive to business that will greatly promote entrepreneurship. In this context, government policy is any course of action that aims at regulating and improving the conditions of SMEs in terms of support, implementation, and funding policies. Based on government policy as it relates to entrepreneurial practice through encouraging entrepreneurship by making a favourable environment for the entrepreneurs (entrepreneurial environment, environment for entrepreneurship). Furthermore, government needs to enact policies that would be user friendly to entrepreneurs. Pals (2006) argues that - in order to achieve the goals of, often lacking, guidelines - there is a need for government policies that support the successful implementation of entrepreneurship irrespective of which administration is in power. Governments of most countries - especially developing countries - in the past invested much effort and resources in establishing policies intended to uplift startup performance (Oni \& Daniya, 2012).

Maciejewski and Wach (2019) show that the number of born globals - i.e. businesses that are international from their inception - among Polish companies is growing, while their activity is mainly restricted to the European Union.

\section{MATERIAL AND METHODS}

\section{Research Process}

This study combined qualitative and quantitative research methods. Qualitative research method was conducted in focus group discussions with ten chief executive officers of SMEs in Danang city at the meeting room of Statistics Offices that have experience in the field of entrepreneurship. The purpose of this phase was to consider the process of assessing startup performance with open questions, but also to modify observational variables that used to measure the research concepts. All items were measured on a five point Likert scale, on which 1 meant "strongly disagree" and 5 "strongly agree." Based on the measurement items used in prior studies, the interviewer will be asked to clarify the meaning of the question for designing the appropriate questionnaire and to choose the appropriate variables. Variables of a concept were selected according to the principle that most observable variables are 
selected. Observed variables with no choice or few users will not be included in the scale. The result has shown that entrepreneurial performance concept is measured by 02 variables including entrepreneurial ecosystem and startup ecosystem. Moreover, both of them are affected by five variables that include government policy, financial capital, cultural factors, social factors, and human capital. Specifically: (1) Startup performance (4 indicators); (2) Entrepreneurial ecosystem (4 indicators); (3) Startup ecosystem (4 indicators); (4) Human capital (4 indicators); (5) Financial capital (5 indicators); (6) Cultural factor (4 indicators); Social factor (4 indicators); Government policy (5 indicators).

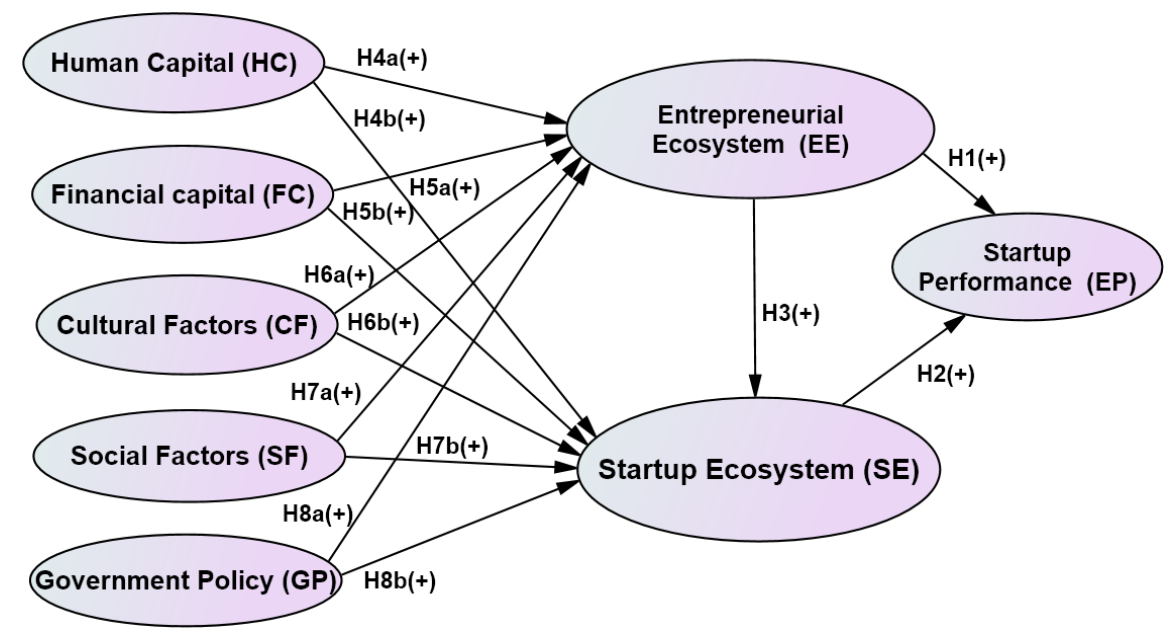

Figure 1. Conceptual model of the factors affecting startup performence Source: own elaboration.

Quantitative research has been conducted through direct interviews (face-to-face interviews) based on a random sample of 320 SMEs in Vietnam, collected from June 2018 to August 2018 with a detailed questionnaire to test model and research hypotheses.

In order to measure a concept in marketing and management research, researchers often do not measure what they want to measure directly (Blumberg, Cooper, \& Schindler, 2014). Moreover, they do not simply measure a concept through a question or a statement. The use of multiple observation variables is more accurate in measuring of a concept (Zikmund, Carr, Griffin, \& Babin, 2013). According to Henseler and Chin (2010), the research model is evaluated in two steps, including the measurement model and structural model. First, we assess the validity of reflective measurement models with the following tools: indicator reliability, internal consistency reliability, convergent reliability, and discriminant validity.

In order to measure the relevance of the model, the reliability of observed variables must have an outer loading factor greater than or equal to 0.5 , which satisfies the reliability requirement, while composite reliability must be greater than or equal to 0.7 (Hulland, 1999).

Convergent validity is used to evaluate the stability of the scale. According to Fornell and Larcker (1981), the average variance extracted (AVE) coefficient must be greater than or equal to 0.5 , which will confirm the convergence value. The load factor of each observation variable is greater than or equal to 0.7 and indicates the reliability of the scales. 
Discriminant validity helps to ensure the difference. There is no correlation between the factors used to measure them. To measure discriminant validity, the square root of AVE is greater than the latent variable correlations between the factor and other factors that indicate the degree of discrimination and reliability of the factor (Fornell \& Larcker, 1981).

Table 1. Testing measurement model

\begin{tabular}{|c|c|c|c|}
\hline Validity Type & Criterion & Description & Literature \\
\hline $\begin{array}{c}\text { Internal } \\
\text { Consistency }\end{array}$ & $\begin{array}{c}\text { Reliability } \\
\text { Cronbach Alpha }\end{array}$ & $\begin{array}{c}\text { Should be greater than } 0.70 \text { to achieve the relia- } \\
\text { ble of measurement model }\end{array}$ & $\begin{array}{l}\text { Nunally } \\
\text { (1978) }\end{array}$ \\
\hline $\begin{array}{c}\text { Internal } \\
\text { Consistency }\end{array}$ & $\begin{array}{c}\text { Reliability Compo- } \\
\text { site Reliability }\end{array}$ & $\begin{array}{c}\text { Alternative to Cronbach Alpha that attempt to } \\
\text { measure the sum of an LV's factor loadings rela- } \\
\text { tive to the sum of the factor loadings plus error } \\
\text { variances }\end{array}$ & $\begin{array}{l}\text { Nunally and } \\
\text { Bernstein } \\
(1994)\end{array}$ \\
\hline $\begin{array}{l}\text { Indicator } \\
\text { Reliability }\end{array}$ & Indicator Loadings & $\begin{array}{l}\text { Measures how much of the indicator's variance is } \\
\text { explained by corresponding latent variables. }\end{array}$ & Chin (1998) \\
\hline $\begin{array}{l}\text { Convergent } \\
\text { Validity }\end{array}$ & $\begin{array}{c}\text { Average Variance } \\
\text { Extracted (AVE) } \\
\end{array}$ & $\begin{array}{l}\text { Proposed threshold value for AVE should be } \\
\text { higher than } 0.50\end{array}$ & $\begin{array}{c}\text { Bagozzi and } \\
\text { Yi (1988) }\end{array}$ \\
\hline $\begin{array}{l}\text { Discriminant } \\
\text { Validity }\end{array}$ & $\begin{array}{l}\text { AVE numbers and } \\
\text { Latent Variable } \\
\text { Correlations }\end{array}$ & $\begin{array}{c}\text { Fornell and Larcker (1981) suggest that the } \\
\text { "square root" of AVE of each latent variable } \\
\text { should be greater than the correlations among } \\
\text { the latent variables }\end{array}$ & $\begin{array}{l}\text { Fornell and } \\
\text { Larcker } \\
(1981)\end{array}$ \\
\hline
\end{tabular}

Source: own study.

Next, the structural model is used to test whether the relationship between the concepts. With t-value $>1.96$, the test is statistically significant at $5 \%$. The outer weights are the criteria for the relative contribution of each indicator. In the structural model, the outer weights are usually lower than the outer loading factor (Hair et al., 2014).

According to Hair, Anderson, Tathham, and Black (1998) if the Maximization Likelihood estimation method is a minimum sample size of 100-150. Moreover, the sample size for the estimation method used in the linear structure (SEM) model is three small sample $\leq 100$, medium sample of $100-200$, and large sample of $\geq 200$. The sample size of this study is 320 suitable for the requirements of the analytical method.

\section{RESULTS AND DISCUSSION}

\section{Description of the Research Sample}

Data is used by PLS-SEM software 3.0 with 320 valid respondents with $91.5 \%$ in all questionnaires of 350 respondents. According to Table 1, there are three main types of surveyed entrepreneurs selected, including limited liability companies with $69.7 \%$, private companies with $13.4 \%$, and other with $16.9 \%$. Moreover, the fields of commerce and service businesses gather the majority of total respondents in Table 2.

These types of surveyed entrepreneurs are appropriate, because Danang is a developing city with a strategic direction in tourism and high technology industry. Until now, the number of large-scale business accounts in Danang city (ca. 90\%) belong to SMEs. Therefore, the sample is suitable for this study. 
Table 2. Types of surveyed entrepreneurs

\begin{tabular}{|l|c|c|c|c|}
\hline \multicolumn{1}{|c|}{ Types } & Frequency & Percent & Valid Percent & Cumulative Percent \\
\hline Limited Liability Company & 223 & 69.7 & 69.7 & 69.7 \\
\hline Private company & 43 & 13.4 & 13.4 & 83.1 \\
\hline Other & 54 & 16.9 & 16.9 & - \\
\hline Total & 320 & 100.0 & 100.0 & - \\
\hline
\end{tabular}

Source: own study.

Table 3. Fields of Business

\begin{tabular}{|l|c|c|c|c|}
\hline \multicolumn{1}{|c|}{ Fields } & Frequency & Percent & Valid Percent & Cumulative Percent \\
\hline Commerce & 122 & 38.1 & 38.1 & 38.1 \\
\hline Service & 100 & 31.3 & 31.3 & 69.4 \\
\hline Tourism & 28 & 8.8 & 8.8 & 78.1 \\
\hline Other & 70 & 21.9 & 21.9 & - \\
\hline Total & 320 & 100.0 & 100.0 & - \\
\hline
\end{tabular}

Source: own study.

Table 4. Results of the construct reliability and validity

\begin{tabular}{|l|c|c|c|}
\hline \multicolumn{1}{|c|}{ Variable } & Cronbach's Alpha & Composite Reliability & Average Variance Extracted (AVE) \\
\hline CF & 0.8377 & 0.8914 & 0.6724 \\
\hline EE & 0.8619 & 0.9061 & 0.7071 \\
\hline EP & 0.8684 & 0.9101 & 0.7169 \\
\hline FC & 0.8657 & 0.9029 & 0.6504 \\
\hline GP & 0.8328 & 0.8818 & 0.5987 \\
\hline HC & 0.8046 & 0.8711 & 0.6286 \\
\hline SE & 0.8466 & 0.8970 & 0.6856 \\
\hline GP & 0.8409 & 0.8933 & 0.6768 \\
\hline
\end{tabular}

Source: own study.

Reliability is tested by measuring the composite reliability and Cronbach's alpha, complemented with indicator loadings. These tests are necessary to make sure there is internal consistency. As Table 4 shows, all scores are above $>0.8$, so they meet the standard of internal consistency. Construct reliability measures the extent of internal consistency of measures used, while the results presented in Table 4 show that the observed variables and independent variables used to measure startup performance concepts are satisfied with Cronbach's Alpha coefficient because they are greater than 0.70, which achieves a reliable measurement model (Nunally, 1978).

Next I checked indicator reliability (see Table 5). One may clearly see here that all indicators have individual indicator reliability values that are much larger than the minimum acceptable level of 0.4 and close to the preferred level of 0.7 . Table 5 represents the outer loadings and shows that all scores are above $>0.7$, so they meet the standards as well.

Fornell Larcker, Cross loadings, and the heterotrait-monotrait ratio (HTMT) are assessment factors to test discriminant validity (Fornell-Larcker, 1981). One assesses discriminant validity through convergent validity and discriminant validity. The criterion of FornellLarcker (1981) is commonly used to assess the degree of shared variance between latent 
variables of a model. According to this criterion, the convergent validity of the measurement model can be assessed by the Average Variance Extracted (AVE) and Composite Reliability (CR). According to the Fornell-Larcker criterion and the cross-loadings (Table 6), the constructs' discriminant validity has been established: (1) the square root of each construct's AVE is higher than its correlation with another construct, and (2) each item loads highest on its associated construct.

Table 5. The results of outer loadings

\begin{tabular}{|c|c|c|c|c|c|c|c|c|}
\hline Variable & CF & $\mathrm{EE}$ & EP & FC & GP & $\mathrm{HC}$ & SE & SF \\
\hline CF1 & 0.8067 & & & & & & & \\
\hline CF2 & 0.8230 & & & & & & & \\
\hline CF3 & 0.8315 & & & & & & & \\
\hline CF4 & 0.8185 & & & & & & & \\
\hline EE1 & & 0.8220 & & & & & & \\
\hline EE2 & & 0.8333 & & & & & & \\
\hline EE3 & & 0.8637 & & & & & & \\
\hline EE4 & & 0.8441 & & & & & & \\
\hline EP1 & & & 0.8377 & & & & & \\
\hline EP2 & & & 0.8735 & & & & & \\
\hline EP3 & & & 0.8370 & & & & & \\
\hline EP4 & & & 0.8380 & & & & & \\
\hline FC1 & & & & 0.7818 & & & & \\
\hline $\mathrm{FC2}$ & & & & 0.8142 & & & & \\
\hline FC3 & & & & 0.8185 & & & & \\
\hline FC4 & & & & 0.7929 & & & & \\
\hline FC5 & & & & 0.8242 & & & & \\
\hline GP1 & & & & & 0.7778 & & & \\
\hline GP2 & & & & & 0.7561 & & & \\
\hline GP3 & & & & & 0.7889 & & & \\
\hline GP4 & & & & & 0.7912 & & & \\
\hline GP5 & & & & & 0.7541 & & & \\
\hline $\mathrm{HCl}$ & & & & & & 0.8140 & & \\
\hline $\mathrm{HC2}$ & & & & & & 0.8055 & & \\
\hline $\mathrm{HC} 3$ & & & & & & 0.7454 & & \\
\hline $\mathrm{HC4}$ & & & & & & 0.8044 & & \\
\hline SE1 & & & & & & & 0.8597 & \\
\hline SE2 & & & & & & & 0.7939 & \\
\hline SE3 & & & & & & & 0.8577 & \\
\hline SE4 & & & & & & & 0.7983 & \\
\hline SF1 & & & & & & & & 0.8077 \\
\hline SF2 & & & & & & & & 0.8227 \\
\hline SF3 & & & & & & & & 0.8098 \\
\hline SF4 & & & & & & & & 0.8497 \\
\hline
\end{tabular}

Source: own study.

Convergent validity can be assessed through construct factor (item) loadings in AVEs - or cross loadings in PLS - that should have the minimum loading of 0.5 and composite reliability (CR) with the acceptable minimum of 0.70 (Fornell \& Larcker, 1981). Table 5 
shows that factor loadings of items to their respective constructs are stronger than they load on other constructs, which provides evidence in support of convergent validity of derived measures. Discriminant validity was considered adequate, since the AVEs are greater than their respective inter-construct correlations, as visible in Table 6. Fornell-Larcker matrix also shows in Table 6 that the top coefficient is greater than the coefficients in the same column. Given that construct reliability and validity conditions of the measurement model are acceptable, we proceed to assess the structural model.

Table 6. The results of Fornell-Larcker Criterion

\begin{tabular}{|c|c|c|c|c|c|c|c|c|}
\hline & CF & EE & EP & FC & GP & $\mathrm{HC}$ & $\mathrm{SE}_{-}$ & SF \\
\hline CF & 0.8200 & & & & & & & \\
\hline $\mathrm{EE}$ & 0.3643 & 0.8409 & & & & & & \\
\hline $\mathrm{EP}$ & 0.4475 & 0.5545 & 0.8467 & & & & & \\
\hline $\mathrm{FC}$ & 0.1991 & 0.4114 & 0.4773 & 0.8065 & & & & \\
\hline GP & 0.1210 & 0.2971 & 0.3414 & 0.2434 & 0.7738 & & & \\
\hline $\mathrm{HC}$ & 0.2031 & 0.3557 & 0.4265 & 0.1911 & 0.1130 & 0.7928 & & \\
\hline SE & 0.4052 & 0.5892 & 0.7144 & 0.4923 & 0.3806 & 0.3929 & 0.8280 & \\
\hline SF & 0.2671 & 0.4208 & 0.4804 & 0.2646 & 0.2713 & 0.2403 & 0.4701 & 0.8227 \\
\hline
\end{tabular}

Source: own study.

Table 7. Heterotrait-Monotrait Ratio (HTMT)

\begin{tabular}{|c|l|l|l|l|l|l|l|}
\hline & \multicolumn{1}{|c|}{ CF } & \multicolumn{1}{c|}{ EE } & \multicolumn{1}{c|}{ EP } & FC & GP & HC & SE \\
\hline EE & 0.4282 & & & & & & \\
\hline EP & 0.5212 & 0.6368 & & & & & \\
\hline FC & 0.2332 & 0.4743 & 0.5493 & & & & \\
\hline GP & 0.1427 & 0.3474 & 0.3993 & 0.2804 & & & \\
\hline HC & 0.2516 & 0.4213 & 0.5063 & 0.2196 & 0.1380 & & \\
\hline SE_ & 0.4768 & 0.6881 & 0.8310 & 0.5727 & 0.4516 & 0.4643 & \\
\hline SF & 0.3138 & 0.4923 & 0.5595 & 0.3112 & 0.3225 & 0.2832 & 0.5549 \\
\hline
\end{tabular}

Source: own study.

HTMT values close to 1 indicate the lack of discriminant validity, while values close to 0.85 indicate threshold values. To assess discriminant validity, the heterotrait-monotrait ratio of correlations (HTMT) is tested. In order to secure discriminant validity, all values must be $<0.85$. Therefore, the results of Table 7 are satisfied with the discriminant validity in the measurement model.

\section{The Results of the Structural (Inner) Model}

After testing the outer models, the inner model is tested by measuring multicollinearity and path coefficients. SmartPLS generates T-statistics for significant tests of both the inner and outer model, using a procedure called bootstrapping. In this procedure, a large number of subsamples (e.g., 5000) are taken from the original sample with a replacement to give bootstrap standard errors, which in turn gives approximate T-values for significance testing of the structural path. Bootstrapping results approximate the normality of data. Multicollinearity is tested by using Variance Inflation Factors (VIF). VIFs values must be lower than 5. As Table 8 shows, there is no collinearity in the model. 
Table 8. Inner VIFs' values

\begin{tabular}{|c|c|c|c|c|c|c|c|c|}
\hline & CF & EE & EP & FC & GP & HC & SE_ & SF \\
\hline CF & 0.0000 & 1.1180 & 0.0000 & 0.0000 & 0.0000 & 0.0000 & 1.2918 & 0.0000 \\
\hline EE & 0.0000 & 0.0000 & 1.0000 & 0.0000 & 0.0000 & 0.0000 & 1.6731 & 0.0000 \\
\hline EP & 0.0000 & 0.0000 & 0.0000 & 0.0000 & 0.0000 & 0.0000 & 2.1752 & 0.0000 \\
\hline FC & 0.0000 & 1.1472 & 0.0000 & 0.0000 & 0.0000 & 0.0000 & 1.3622 & 0.0000 \\
\hline GP & 0.0000 & 1.1191 & 0.0000 & 0.0000 & 0.0000 & 0.0000 & 1.1814 & 0.0000 \\
\hline HC & 0.0000 & 1.1012 & 0.0000 & 0.0000 & 0.0000 & 0.0000 & 1.2618 & 0.0000 \\
\hline SE & 0.0000 & 0.0000 & 0.0000 & 0.0000 & 0.0000 & 0.0000 & 0.0000 & 0.0000 \\
\hline SF & 0.0000 & 1.2171 & 0.0000 & 0.0000 & 0.0000 & 0.0000 & 1.3788 & 0.0000 \\
\hline
\end{tabular}

Source: own study.

The significance of the path coefficients are measured by executing the Bootstrap method using 5.000 single performances. The results show significant relationship between vartiables in the model ( $p$ values $<0.05$ ).

Table 9. Path coefficients

\begin{tabular}{|c|c|c|c|c|c|}
\hline Path & $\begin{array}{c}\text { Original } \\
\text { Sample (0) }\end{array}$ & $\begin{array}{c}\text { Sample } \\
\text { Mean (M) }\end{array}$ & $\begin{array}{c}\text { Standard Devia- } \\
\text { tion (STDEV) }\end{array}$ & $\begin{array}{c}\text { T Statistics } \\
\text { (|O/STDEV) }\end{array}$ & $\begin{array}{c}\text { P Val- } \\
\text { ues }\end{array}$ \\
\hline CF -> EE & 0.2007 & 0.1971 & 0.0475 & 4.2253 & 0.0000 \\
\hline CF -> SE & 0.0804 & 0.0797 & 0.0384 & 2.0949 & 0.0367 \\
\hline EE -> EP & 0.5545 & 0.5545 & 0.0370 & 14.9766 & 0.0000 \\
\hline EE -> SE & 0.1805 & 0.1792 & 0.0432 & 4.1820 & 0.0000 \\
\hline EP -> SE & 0.3871 & 0.3858 & 0.0511 & 7.5716 & 0.0000 \\
\hline FC -> EE & 0.2431 & 0.2431 & 0.0462 & 5.2562 & 0.0000 \\
\hline FC -> SE & 0.1482 & 0.1477 & 0.0420 & 3.5286 & 0.0005 \\
\hline GP -> EE & 0.1316 & 0.1330 & 0.0447 & 2.9404 & 0.0034 \\
\hline GP -> SE & 0.1134 & 0.1141 & 0.0412 & 2.7540 & 0.0061 \\
\hline HC -> EE & 0.2010 & 0.2001 & 0.0472 & 4.2554 & 0.0000 \\
\hline HC -> SE & 0.0829 & 0.0850 & 0.0373 & 2.2226 & 0.0267 \\
\hline SF -> EE & 0.2188 & 0.2178 & 0.0463 & 4.7288 & 0.0000 \\
\hline SF -> SE & 0.0968 & 0.0980 & 0.0413 & 2.3404 & 0.0197 \\
\hline
\end{tabular}

Source: own study.

As Table 9 reveals, the original sample and sample mean of bootstrapping results from 5000 are in the $95 \%$ confidence interval. Thus, we may conclude the estimates in the model as reliable. The conceptual model and its path coefficients (including P values) appear in Table 9.

Figure 2 and Table 9 confirm thirteen hypotheses of this study $(\mathrm{H} 1, \mathrm{H} 2, \mathrm{H} 3, \mathrm{H} 4 \mathrm{a}, \mathrm{H} 4 \mathrm{~b}, \mathrm{H} 5 \mathrm{a}$, $\mathrm{H} 5 \mathrm{~b}, \mathrm{H} 6 \mathrm{~A}, \mathrm{H6B}, \mathrm{H7A}, \mathrm{H7B}, \mathrm{H} 8 \mathrm{~A}, \mathrm{H8B}$ ), because of the statistical value $\mathrm{t}>1.96$ (or $\mathrm{P}$-value $<5 \%$ ).

The results of testing indicate the suitability of the research model with data's research, while the acceptance of the hypotheses in this research model show the practical meaning for startup performance. Thus, this research determined the impact of every factor that constitutes the entrepreneurial ecosystem and startup ecosystem on startup performance of SMEs in Danang city. The equation (1) shows the affection on SE and EE to EP:

$$
\mathbf{E P}=0.594 \mathbf{S E}+0.204 \mathbf{E E}
$$




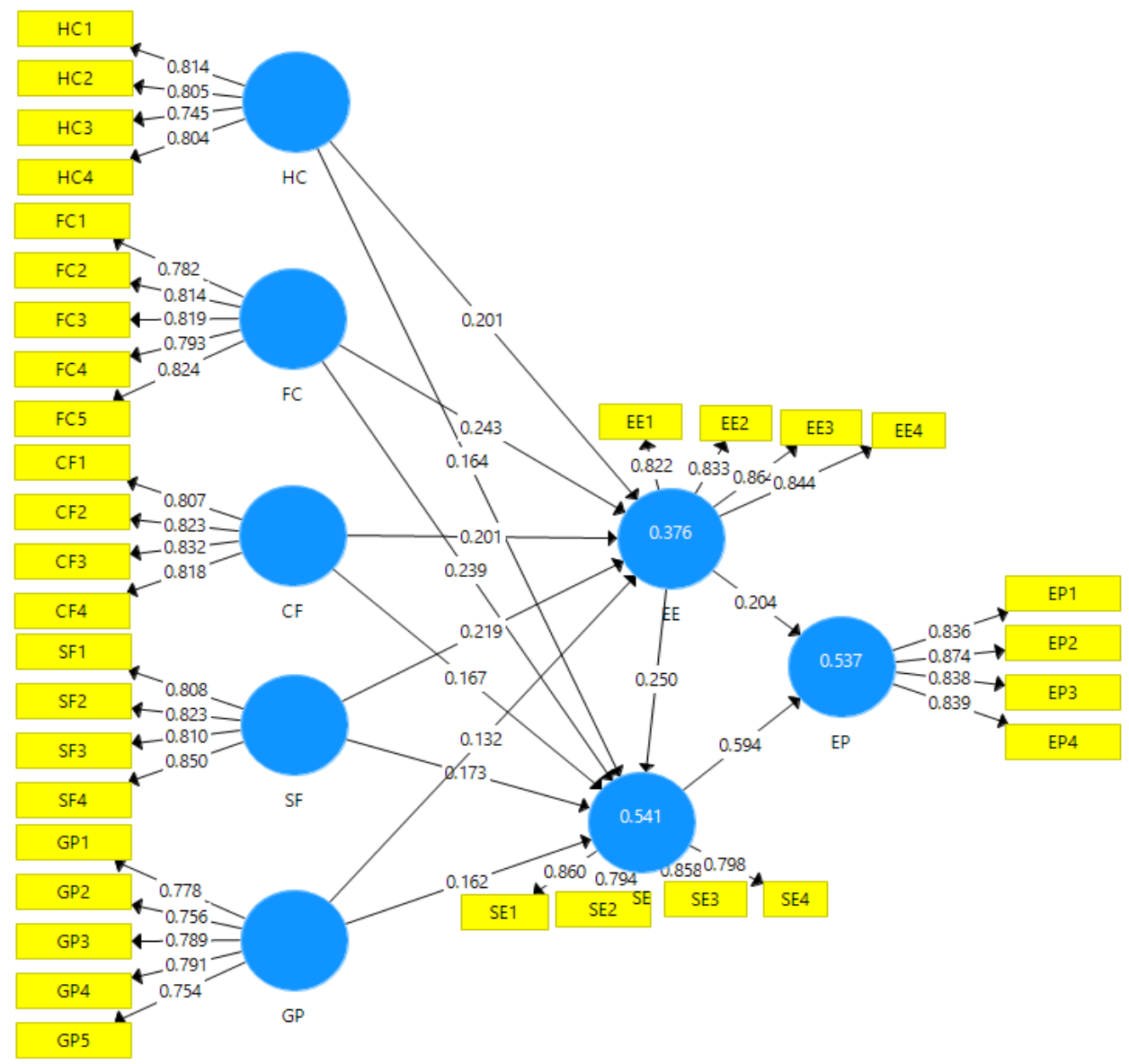

Figure 2. Results of applied the PLS-SEM model Source: own elaboration.

As in the above equation (1), SE affects EP the strongest because it has the highest coefficient of 0.594 . The results identify the priority of factors in the research model. Specifically, financial capital and human capital emerge as the strongest factors that affect the entrepreneurial ecosystem. For a sustainable startup, there should be suitable legal policies that include tax incentives in the first 3-5 years, when new businesses are established. Moreover, focus on policies such as credit guarantees and loan assistance for startup enterprises in the initial stage would ease their problems. Furthermore, governments should assist incentive loans to boost SMEs. It is important to invest in human resources and cultural factors. The government should have specific education programs for startups at high schools. The education system needs to adjust in the direction of linking theory with practice, thus linking education with practical activities to promote entrepreneurial culture. Moreover, the education programs must expand in many other ways to enhance people's 
startup interest. There are many studies on entrepreneurship but most treat startup performance in a vague and abstract manner, as they focus on researching entrepreneurship ecosystem (Rahatullah, 2013) or describe the characteristics of entrepreneurship ecosystem (Isenberg, 2011). Besides, other studies evaluate startup environment by analyzing startup ecosystem (Neeraj, 2018) and international factors (Maciejewski \& Wach, 2019) Therefore, we should switch to a more detailed action-oriented form to achieve a successful startup performance. This research study shows the relationship of entrepreneurial ecosystem, startup ecosystem, and startup performance.

\section{CONCLUSIONS}

The research results help policy makers understand important factors affecting startup performance, This study contributes to the testing of the measurement scale of startup performance to start a business in developing countries like Danang, Vietnam. These results will help researchers have suggestions about the measurement system of startup performance which can evaluate success of SMEs in the given market (Danang city). In addition, this scale system can be used as a basis to form a unified scale system in multi studies of startup performance for regions similar to Danang.

This study has its limitations. It only investigates startup performance of SMEs in Danang, not all Vietnam. The convenient non-probability sampling method was applied, this means the ability to generalize is not high. In order to generalize startup performance for all SMEs in Vietnam, researchers should begin with the results from this study. Based on empirical results the following implication for practice should be drawn. For a sustainable startup, there should be suitable legal policies, including incentive policies on taxes in the first 3-5 years, when new businesses are established. Moreover, we should focus on policies such as credit, guarantee, and loan assistance for startup enterprises in their initial stages to solve their problems.

\section{REFERENCES}

Ács, Z.J., Autio, E., \& Szerb, L. (2014). National Systems of Entrepreneurship: Measurement issues and policy implications. Research Policy, 43(3), 476-494. https://doi.org/10.1016/j.respol.2013.08.016

Appuhami, B.A.R. (2007). The Impact of Intellectual Capital on Investors' Capital Gains on Shares: An Empirical Investigation of Thai Banking, Finance \& Insurance Sector. 3(2), 14-25.

Atieno, R. (n.d.). Linkages, Access to Finance and the Performance of Small-Scale Enterprises in Kenya. (Working Paper 6/2009). Helsinki: UNU-WIDER..

Audretsch, D., \& Keilbach, M. (2004). Entrepreneurship Capital and Economic Performance (Vol. 38). https://doi.org/10.1080/0034340042000280956

Blumberg, B., Cooper, D., \& Schindler, P.S. (2014). Business research methods (Book, 2014) [WorldCat.org]. Retrieved from https://www.worldcat.org/title/business-research-methods/oclc/879166049?referer=di\&ht=edition on August 15, 2019.

Bosma, N., van Praag, M., Thurik, R., \& de Wit, G. (2004). The Value of Human and Social Capital Investments for the Business Performance of Startups. Small Business Economics, 23(3), 227236. https://doi.org/10.1023/B:SBEJ.0000032032.21192.72 
Brüderl, J., \& Preisendörfer, P. (1998). Network Support and the Success of Newly Founded Business. Small Business Economics, 10(3), 213-225. https://doi.org/10.1023/A:1007997102930

Chin, W.W. (1998). The partial least squares approach for structural equation modeling. In G.M. Marcoulides (Ed.), Methodology for Business and Management. Modern methods for business research (pp. 295-336). Mahwah, NJ, US: Lawrence Erlbaum Associates Publishers. George A. Marcoulides

Chin, W.W., Marcolin, B.L., \& Newsted, P.R. (2003). A Partial Least Squares Latent Variable Modeling Approach for Measuring Interaction Effects: Results from a Monte Carlo Simulation Study and an Electronic-Mail Emotion/Adoption Study. Information Systems Research, 14(2), 189-217. https://doi.org/10.1287/isre.14.2.189.16018

Coleman, S. (2007). The Role of Human and Financial Capital in the Profitability and Growth of Women-Owned Small Firms. Journal of Small Business Management, 45, 303-319. https://doi.org/10.1111/j.1540-627X.2007.00214.x

Cutoff criteria for fit indexes in covariance structure analysis: Conventional criteria versus new alternatives: Structural Equation Modeling: A Multidisciplinary Journal: Vol 6, No 1. (n.d.). Retrieved from https://www.tandfonline.com/doi/abs/10.1080/10705519909540118 on April 11, 2019.

Dana, L.P. (1994). A Marxist Mini-Dragon? Entrepreneurship in Today's Vietnam. Journal of Small Business Management, 32(2), 95.

Drnovsek, M., \& Hisrich, R. D. (2002). Entrepreneurship and small business research - an European perspective. Journal of Small Business and Enterprise Development, 9(2), 172-222. https://doi.org/10.1108/14626000210427348

Elfring, T., \& Hulsink, W. (2007). Networking by Entrepreneurs: Patterns of Tie-Formation in Emerging Organizations. Organization Studies, 28(12), 1849-1872. https://doi.org/10.1177/0170840607078719

Florin, J., Lubatkin, M., \& Schulze, W. (2003). A Social Capital Model of High-Growth Ventures. The Academy of Management Journal, 46(3), 374-384. https://doi.org/10.2307/30040630

Gilbert, B.A., McDougall, P.P., \& Audretsch, D.B. (2006). New Venture Growth: A Review and Extension. Journal of Management, 32(6), 926-950. https://doi.org/10.1177/0149206306293860

Glodowska, A., Pera, B., \& Wach, K. (2016). The International Environment and Its Influence on the Entrepreneurial Internationalization of Firms: The Case of Polish Businesses. Problemy Zarzqdzania, 14(62), 107-130.

Goswami, A., \& Basu, A. (1999). South Asian entrepreneurship in Great Britain: Factors influencing growth. International Journal of Entrepreneurial Behavior \& Research, 5(5), 251-275. https://doi.org/10.1108/13552559910300381

Gudmundson, D., Tower, C.B., \& Hartman, E.A. (2003). Innovation in Small Businesses: Culture and Ownership Structure Do Matter. Journal of Developmental Entrepreneurship, 8(1), 1-17.

Gudmundson, D., Hartman, E.A., \& Tower, C.B. (1999). Strategic Orientation: Differences between Family and Nonfamily Firms. Family Business Review, 12(1), 27-39. https://doi.org/10.1111/j.1741-6248.1999.00027.x

Hair, F. Jr., Sarstedt, M., Hopkins, L., \& Kuppelwieser, V. (2014). Partial Least Squares Structural Equation Modeling (PLS-SEM): An Emerging Tool for Business Research. European Business Review, 26, 106-121. https://doi.org/10.1108/EBR-10-2013-0128

Hair, F. Jr., Tathham, R.L., Anderson, E.T., \& Black, W.C. (1998). Multivariate data analysis: With Reading (5th ed.). EngleWood Cliffs: Prentice Hall.

Hayer, J.S., \& Ibeh, K.I.N. (2006). Ethnic networks and small firm internationalisation: A study of UK-based Indian enterprises. International Journal of Entrepreneurship and Innovation Management, 6(6), 508-525. https://doi.org/10.1504/IJEIM.2006.010978 
Henseler, J., Dijkstra, T.K., Sarstedt, M., Ringle, C.M., Diamantopoulos, A., Straub, D.W., ... Calantone, R.J. (2014). Common Beliefs and Reality About PLS: Comments on Rönkkö and Evermann (2013). Organizational Research Methods, 17(2), 182-209. https://doi.org/10.1177/1094428114526928

Hoffmann, A. (2007). A Framework for Addressing and Measuring Entrepreneurship. Paris: OECD.

Hurley, R.F., \& Hult, G.T.M. (1998). Innovation, Market Orientation, and Organizational Learning: An Integration and Empirical Examination. Journal of Marketing, 62(3), 42. https://doi.org/10.2307/1251742

Ihugba, O.A., Odii, A., \& Njoku, A.C. (2014). Theoretical Analysis of Entrepreneurship Challenges and Prospects in Nigeria. International Letters of Social and Humanistic Sciences (ILSHS), 5, 21-34.

Introducing the Entrepreneurship Ecosystem: Four Defining Characteristics. (n.d.). Retrieved from https://www.forbes.com/sites/danisenberg/2011/05/25/introducing-the-entrepreneurshipecosystem-four-defining-characteristics on July 31, 2019.

Katila, R., Chen, E., \& Piezunka, H. (2012). All the Right Moves: How Entrepreneurial Firms Compete Effectively (SSRN Scholarly Paper No. ID 2372663). Retrieved from Social Science Research Network website: https://papers.ssrn.com/abstract=2372663

Keh, H.T., Nguyen, T.T.M., \& Ng, H.P. (2007). The effects of entrepreneurial orientation and marketing information on the performance of SMEs. Journal of Business Venturing, 22(4), 592-611. https://doi.org/10.1016/j.jbusvent.2006.05.003

Kumar, S., \& Liu, D. (2005). Impact of globalisation on entrepreneurial enterprises in the world markets. International Journal of Management and Enterprise Development, 2(1), 46-64. https://doi.org/10.1504/IJMED.2005.006026

Maciejewski, M., \& Wach, K. (2019). International Startups from Poland: Born Global or Born Regional? Journal of Management and Business Administration. Central Europe, 27, 60-83. https://doi.org/10.7206/jmba.ce.2450-7814.247

Man, T.W.Y., Lau, T., \& Chan, K.F. (2002). The competitiveness of small and medium enterprises: $A$ conceptualization with focus on entrepreneurial competencies. https://doi.org/10.1016/S0883-9026(00)00058-6

Mirror, mirror on the wall: A comparative evaluation of composite-based structural equation modeling methods | springerprofessional.de. (n.d.). Retrieved from https://www.springerprofessional.de/en/mirror-mirror-on-the-wall-a-comparative-evaluation-of-composite-/12072768 on April 11, 2019.

Mitchell, R., Smith, J., Morse, E., Seawright, K.W., Peredo, A.M., \& McKenzie, B. (2002). Are entrepreneurial cognitions universal? Assessing entrepreneurial cognitions across cultures. Entrepreneurship Theory and Practice, 26, 9-32.

Okten, C., \& Osili, U. (2004). Contributions in heterogeneous communities: Evidence from Indonesia. Journal of Population Economics, 17(4), 603-626.

Oni, E.O. (2012). Development of Small and Medium Scale Enterprises: The role of Government and other Financial Institutions By: 1, 14.

Pandey, N. (2018). An analysis of startup ecosystem in metropolitan city in India. International Journal of Engineering and Management Research, 8. https://doi.org/10.31033/ijemr.v8i02.12029

Rahatullah Khan, M. (2013). Mapping entrepreneurship ecosystem of Saudi Arabia. World Journal of Entrepreneurship, Management and Sustainable Development, 9(1), 28-54. https://doi.org/10.1108/20425961311315700

Refining the definition of entrepreneurship - ProQuest. (n.d.). Retrieved from https://search.proquest.com/docview/304825438 on July 31, 2019. 
Subramony, M., Segers, J., Chadwick, C., \& Shyamsunder, A. (2018). Leadership development practice bundles and organizational performance: The mediating role of human capital and social capital. Journal of Business Research, 83, 120-129. https://doi.org/10.1016/j.jbusres.2017.09.044

Szabó, D.A. (n.d.). Business Incubation as Element of Business Service Institution and Sme Development Infrastructure for Creation of New Enterprises. Budapest: ERENET.

Thorndike, R.M. (1995). Book Review: Psychometric Theory (3rd ed.) by Jum Nunnally and Ira Bernstein New York: McGraw-Hill, 1994, xxiv + 752 pp. Applied Psychological Measurement, 19(3), 303-305. https://doi.org/10.1177/014662169501900308

Tsujimoto, M., Kajikawa, Y., Tomita, J., \& Matsumoto, Y. (2018). A review of the ecosystem conceptTowards coherent ecosystem design. Technological Forecasting and Social Change, 136, 49-58. https://doi.org/10.1016/j.techfore.2017.06.032

Ucbasaran, D., Westhead, P., \& Wright, M. (2001). The Focus of Entrepreneurial Research: Contextual and Process Issues. Entrepreneurship Theory and Practice, 25. (N.d.).

Zikmund, G.A., Babin, B. J., Carr, J. C.,\& Griffin, M. (2013). Business Research Method. New York: Griffin Publishers.

\section{Author}

\section{Trinh Le Tan}

Assistant Professor at International School, Duy Tan University (Vietnam). His research interests includes entrepreneurship, green business, operation and supply chain, Blanced Scorecard.

Correspondence to: Dr Trinh Le Tan, International School, Duy Tan University, 254 Nguyen Van Linh Street, Thanh Khe District, Danang city 550000, Vietnam, email: letandtu@gmail.com ORCID (1) http://orcid.org/0000-0001-7729-3241

\section{Copyright and License}

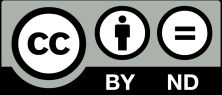

This article is published under the terms of the Creative Commons

Attribution - NoDerivs (CC BY-ND 4.0) License http://creativecommons.org/licenses/by-nd/4.0/

Published by the Centre for Strategic and International Entrepreneurship - Krakow, Poland

Ministry of Science and Higher Education Republic of Poland
The copyediting and proofreading of articles in English is financed in the framework of contract No. 913/P-DUN/2019 by the Ministry of Science and Higher Education of the Republic of Poland committed to activities aimed at science promotion. 